\title{
ANALYSIS OF PARKING FEASIBILITY CAPACITY AT LANDUNGSARI MARKET, DAU DISTRICT, MALANG REGENCY
}

\author{
Rifky Aldila $\mathbf{P}^{\mathbf{1}}$, Andy Kristafi $\mathbf{A}^{\mathbf{2}}$ \\ ${ }^{1}$ Civil Engineering Study Program, Faculty of Engineering, Tribhuwana Tunggadewi \\ University Malang \\ ${ }^{2}$ Civil Engineering Study Program, Faculty of Engineering, Tribhuwana Tunggadewi \\ University Malang, Indonesia \\ e-mail: rifky.unitrimalang@gmail.com
}

\begin{abstract}
Landungsari Market is one of the traditional markets built by the local village government to accelerate the village economy. Previously, Landungsari Market was a temporary market but with an increase in sellers who were moved from the original Merjosari market so that the local government made the Landungsari market a permanent market today. With the increasing number of seller stalls in the Landungsari market, the parking lot in the Landungsari market has decreased so that it demands the possibility of illegal parking occurs in some areas of the market. The research objective was to determine the characteristics of parking, parking feasibility, and parking solutions. The data used are primary data and secondary data. The results obtained in this study are the number of parking spaces is still less than the number of parking vehicles, namely for two-wheeled parking lots, the parking needs exceed the normal capacity, while the average motorbike parking space unit is 129 parking spaces and the average The car park space unit is 11 parking spaces, so with this condition, it is deemed inappropriate parking facilities and additional parking lots to increase the parking capacity of vehicles, especially for two-wheeled vehicles
\end{abstract}

Keywords: Characteristics, Parking Feasibility, Landungsari Market

\section{Introduction}

The definition of a market is a market that develops and expands in the surrounding community [1], especially native traders or indigenous traders. One of the traditional markets is the Landungsari market.

Landungsari Market is one of the traditional markets built by the local village government to accelerate the village economy. Previously, the Landungsari market was empty of visitors but in recent years it was crowded with many visitors, this was due to the relocation of many traders from the Merjosari market, thus adding to merchant stalls and various Landungsari market facilities. Previously, the Landungsari market was a temporary market, but with the increase in sellers who were moved from the original Merjosari market, the local government made the Landungsari market a permanent market today. The above perception is reinforced by several questions posed to several market officials and market visitors who say that the landungsari market was previously a temporary market but turned into a permanent market due to the increase in sellers and visitors. With the increasing number of seller stalls in the Landungsari market, the parking lot in the Landungsari market has decreased, demanding the possibility of illegal parking in some areas of the market. At the peak time of the visit, vehicles can still be found parked arbitrarily and cannot enter the parking lot because the parking provided is full so vehicles likely tend to be parked anywhere. The high (i) (2) 7 
number of vehicles parked in any place will hinder every movement of people themselves in the Landungsari market in their shopping activities.

This research aims to find out the characteristics of parking, to know the feasibility of parking in the market, and to find out the alternative parking area arrangement in the Malang Landungsari market.

\section{Methods}

Parking is defined as a vehicle that stops at certain places, whether stated with a sign or not and is not solely for loading or unloading people and goods. Meanwhile, another definition of parking is a condition where a vehicle stops for a while (unloads) or stops for a long time [2].

\subsection{Parking Activities}

Parking activity is the tendency for vehicle users to do parking [3] and can be divided into two as follows:

\subsection{Fixed Parking Activities}

1) Trade centers (markets, retail, and supermarkets)

2) Private and government office centers

3) Schools and Universities

4) A place of recreation

5) Hotels and lodging

6) Hospital

\subsection{Temporary parking activities}

1) Cinema building

2) The venue for sports competitions

\subsection{Type of Parking}

Vehicles taking a trip will eventually stop at their destination, requiring parking space. Below are several types of parking available:

1. Parking according to placement [4]

1. On-Street Parking

2. Parking lot

3. Multi-storey parking building

4. Parking According to Status

5. Public Parking

6. Special Parking

7. Emergency / Incidental Parking

8. Park Parking

9. Parking Building

2. Parking According to the Purpose

1. Passenger parking is parking to raise and lower passengers.

2. Parking for goods, namely parking for loading/unloading goods. The two of them were deliberately separated so as not to interfere with their respective activities and needs.

3. Parking according to the type of ownership and operation

1. Parking owned and operated by Local Government.

2. Parking belongs to the Regional Government and the operator is the private sector.

3. Parking owned and operated privately 


\subsection{Accumulated Parking}

This information is needed to determine the number of vehicles parked on the available land at certain intervals. This data can be obtained by counting the vehicles that have used the parking lot plus the incoming vehicles and subtracting the outgoing vehicles

\subsection{Parking Volume}

Parking volume, parking volume is the vehicle involved in a parking load (ie vehicles per a certain period of time, usually per day) [5]. The parking volume can be calculated by adding up the vehicles that use the parking area at a certain time.

\subsection{Average Parking Length (Duration)}

Average parking time is the average length of time taken for each vehicle to stop at a parking space. The average length of parking is expressed in hours/vehicle. A parking space will be able to serve more vehicles if the parking time is short, compared to the parking space used by the vehicle for a long time [6].

\subsection{Parking Index (IP)}

The parking index is a comparison between parking accumulation and parking capacity. This parking index value can show how much parking capacity has been filled [7]

a. IP $<1$ means that the parking facility has no problem, where the parking requirement does not exceed the normal capacity/capacity

b. IP $=1$ means that parking needs are balanced with normal capacity.

c. IP> 1 means that the parking facility has a problem, where the parking requirement exceeds the normal capacity/capacity.

\subsection{Satuan Ruang Parkir (SRP) / Parking Space Units}

The parking space unit, which is usually abbreviated as SRP, is a measure of the effective area for placing a vehicle, in this case a passenger car, bus / truck, or motorbike, whether parallel motorbikes on the side of the road, parking lot or parking building, SRP must consider the free space and width of door openings. In a controlled parking lot, it requires a marker on the road surface to facilitate the parking activity itself. Additional space is needed to transfer motion, which depends on the parking angle. The parking angle is determined based on the following considerations:

- Safety, order and smooth traffic.

- Road and environmental conditions.

\subsection{Method of collecting data}

\section{A. Primary data}

Primary data is a source of data obtained directly from the source (not through intermediary media). Primary data can be in the form of individual or group opinion of the subject (person), the results of observations on an object (physical), events or activities, and test results. The method used to obtain primary data is observation and documentation [8].

\section{B. Secondary Data}

Secondary data is a source of research data obtained indirectly through intermediary media. Secondary data is generally in the form of evidence, historical records, or reports that have been compiled in published and unpublished archives. secondary data include road network data, land use, RTRW / RDTR, and Site Plane [9].

\section{Data Analysis Method}

Methods of data analysis in this study using quantitative methods. The data analysis steps include [10] :

1) Accumulated Parking

2) Parking volume

3) Parking Index (IP)

4) Parking Space Unit (SRP) 


\section{Result and Discussion}

\subsection{General condition}

Landungsari Malang Market is located on Jalan Tirto Rahayu Malang, Landungsari Village. This market accommodates shipments of the necessities of vegetables, fruits, and other staples. The Landungsari Market in Malang is active for about 6 hours every day with traders in the market who are active from morning to $12.00 \mathrm{WIB}$ and also the status of Landungsari market land island belonging to the government of Landungsari village which is allocated to the village to become a market. The total market area is $6100 \mathrm{~m} 2$ which is allocated for several market activities including a market building of $5900 \mathrm{~m} 2$, two-wheeled parking needs $200 \mathrm{~m} 2$.

Landungsari market parking has parking plots each, namely 65 two-wheeled vehicles with a length of $20 \mathrm{~m} \times 10 \mathrm{~m}$ width, while four-wheeled vehicles totaling 20 plots with a length of $50 \mathrm{~m} \mathrm{x}$ $35 \mathrm{~m}$ width. The condition of the parking location in Malang Landungsari Market is also irregular. This can be seen from the untidy parking lot and parking mixed with Market activities.

Apart from market activity, trading activities also occur outside the market such as shops and kiosks. Trading activities outside the market have created new traffic problems and parking needs that need to be accommodated. Parking in Malang Landungsari Market is not neatly arranged because it is still mixed with Market activities. The problem found in the research location was that the parking lot was still insufficient so that there were still some vehicles parked outside the main parking lot and parked anywhere.

\subsection{Parking characteristics analysis}

Parking characteristics are related to the amount of parking required that must be provided. In parking characteristics, it is necessary to know a number of things that are commonly used as described below:

\section{- $\quad$ Parking Volume}

Parking volume is the vehicle involved in a parking load, namely the vehicles per certain time period, usually per day. The determination of the parking volume of vehicles in the Landungsari Malang market uses the equation:

Parking Volume $=\mathrm{Ei}+\mathrm{X}$

- Two-wheeled parking volume analysis is as follows:

Parking Volume $=\mathrm{Ei}+\mathrm{X}$

With:

Ei : vehicles that enter the parking location

$\mathrm{X}$ : number of existing vehicles

Data on two-wheeled vehicles at $06.00-06.15$ are as many as 45 vehicles while the previous vehicle was not available so the parking volume at $06.00-06.15$ is as follows:

Parking volume $\quad=45+0$

$$
=45 \text { vehicle }
$$

The highest parking peak volume occurred at $07.15-07.30$ at 118 vehicles with a total parking volume in the 6 hours of the study of 1373 vehicles. Judging from the existing parking plots, which only have 65 parking lots, it can be concluded that the vehicle volume exceeds the existing parking lots.

\section{- Four-wheeled parking volume analysis is as follows:}

Four-wheeled vehicle data entered at $06.00-06.15$, which is as many as 11 vehicles while the previous vehicle was not available so the parking volume at $06.00-06.15$ is as follows: The highest parking peak volume occurred at 07.15-07.30 at 118 vehicles with a total parking volume in the 6 hours of the study of 1373 vehicles. Judging from the existing parking plots, which only have 65 parking lots, it can be concluded that the vehicle volume exceeds the existing parking lots.

Parking volume $=\mathrm{Ei}+\mathrm{X}$

$=11+0$

$$
=11 \text { vehicle }
$$


The highest parking peak volume occurred at $06.00-06.15$ with 11 vehicles with a total parking volume in the 6 hours of the study of 116 vehicles. Judging from the existing parking conditions of 20 parking lots, it can be concluded that the vehicle volume does not exceed the existing parking plots.

\section{- Parking Duration Analysis}

Parking time is stated in hours. A parking space will be able to serve more vehicles if it is used for parking in a short time or when compared to a parking space that is used to park vehicles for a long time. The results of parking duration analysis can be obtained using the formula:

$$
\mathrm{D}=\left(\begin{array}{lll}
N x & \mathrm{x} & \mathrm{I}
\end{array}\right) / \mathrm{Nt}
$$

Information:

D : Average parking length / duration (hour / vehicle).

$\mathrm{Nx}$ : The number of parked vehicles during the survey time interval

$\mathrm{X}$ : The number of intervals.

$\mathrm{Nt}$ : The total number of vehicles during the survey time

- Two-wheeled parking duration analysis

Data on two-wheeled vehicles for one hour (60 minutes) were 185 vehicles, while the number of vehicles during the survey time was 929 vehicles. The results of the two-wheeled parking duration analysis are as follows:

$$
\begin{aligned}
\mathrm{D} & =(N x \times \mathrm{I}) / \mathrm{Nt} \\
& =(185 \times 60) / 929 \\
& =11,97 \text { minutes/vehicle }
\end{aligned}
$$

The average peak volume of two-wheeled parking per hour is 155 vehicles with an average parking volume of 10 minutes / vehicle.

\section{- $\quad$ Four-wheeled parking duration analysis}

Data on four-wheeled vehicles for one hour (60 minutes) were 19 vehicles, while the number of vehicles during the survey time was 78 vehicles. The results of the analysis of four-wheeled parking duration are as follows:

$\mathrm{D} \quad=(\mathrm{Nx} \times \mathrm{I}) / \mathrm{Nt}$

$$
=(19 \times 60) / 78
$$

$=14,62 \mathrm{menit} / \mathrm{kend}$

The average peak volume of four-wheeled parking per hour is 13 vehicles with an average parking volume of 10 minutes / vehicle.

\section{- Accumulated Parking}

Accumulated parking is the total number of parking lots at a place at a certain time and divided according to the category of the type of travel intent, where the integration of the accumulated parking during a certain period shows the parking load (number of parking vehicles) in vehicle hours per certain time period.

The results of the analysis of vehicle parking accumulation using incoming vehicles plus the initial accumulation minus outgoing vehicles for each vehicle in a time period of one hour. Examples of parking accumulation calculations are as follows:

Akumulated Parking $=($ Ei - Ex $)+X$

With:

Ei: vehicles that enter the parking location

Ex: vehicles exiting the parking location

$\mathrm{X}$ : number of existing vehicles

\section{- Two-wheeled parking accumulation analysis}

The data for two-wheeled two-wheeled vehicles is 45 vehicles, 41 vehicles out of the way while the previous number of vehicles does not exist so the results of the two-wheeled parking accumulation analysis are as follows: 

Akumulated Parking $=(\mathrm{Ei}-\mathrm{Ex})+\mathrm{X}$
$=(45-41)+0$
$=4$ Vehicle

Based on the two-wheeled parking accumulation analysis above, it is known that the average accumulation of parking is 19 vehicles, while the maximum accumulation is 77 vehicles and occurs at $07.15-07.30$. The accumulation of two-wheeled vehicles exceeds the existing parking lots, namely 65 parking lots.

\section{- Four-wheeled parking accumulation analysis}

Data on four-wheeled vehicles were 11 vehicles, outgoing vehicles were 9 vehicles, while the previous number of vehicles did not exist so the results of the four-wheeled parking accumulation analysis were as follows:

$$
\begin{aligned}
\text { Akumulaated Parking } & =(\mathrm{Ei}-\mathrm{Ex})+\mathrm{X} \\
& =(11-9)+0 \\
& =2 \text { vehicle }
\end{aligned}
$$

Based on the four-wheeled parking accumulation analysis above, it is known that the average accumulation of parking is 2 vehicles, while the maximum accumulation is 7 vehicles and occurs at $08.00-08.15$. the accumulation of four-wheeled vehicles does not exceed the existing parking lots, namely 20 parking lots.

\section{- $\quad$ Parking capacity}

The capacity of the parking space is the maximum capacity of the space to accommodate the vehicle, in this case the volume of the vehicle using the parking facility. The results of the analysis of vehicle parking capacity by dividing the number of parking lots (number of plots) by the average length of parking. Example of calculating parking capacity as follows:

$$
\mathrm{KP}=\frac{S}{D}
$$

Where:

$\mathrm{KP}=$ Parking capacity (vehicle / hour)

$\mathrm{S}=$ Number of parking lots (number of squares $=65$ squares)

$\mathrm{D}=$ Average length of parking (hour / vehicle)

\section{- Two-wheeled parking capacity analysis}

The capacity data of two-wheeled parking plots is 65 plots and the parking duration in one hour period is 11.95 minutes / vehicle, so the results of the two-wheeled parking capacity analysis are as follows:

$$
\begin{aligned}
\mathrm{KP} & =\frac{S}{D} \\
& =\frac{65}{11,95} \\
& =5,44 \text { Vehicle/Hour or } 6 \text { Vehicle /hour }
\end{aligned}
$$

The results of the analysis of the average parking capacity show that two-wheeled vehicles are 2 vehicles / hour. Analysis of the average parking capacity found that two-wheeled vehicles were 8 vehicles / hour.

\section{- $\quad$ Four-wheeled parking capacity analysis}

The capacity data of four-wheeled parking plots is 20 plots and the duration of parking in a onehour period is 14.62 minutes / vehicle, so the results of the analysis of four-wheeled parking capacities are as follows:

$$
\begin{aligned}
\mathrm{KP} & =\frac{S}{D} \\
\mathrm{KP} & =\frac{20}{14,62}=1,37 \text { vehicle/hour } \\
& =2 \text { vechicle/hour }
\end{aligned}
$$


Analysis of the average parking capacity shows that four-wheeled vehicles are 2 vehicles / hour.

\section{- $\quad$ Parking Index}

The parking index is a comparison between parking accumulation and parking capacity. This parking index value can show how much parking capacity has been filled.

The highest parking index is obtained from the comparison between parking accumulation and parking capacity. This parking index will show whether the parking area is problematic or not.

\section{- Two-wheeled parking index analysis}

The average accumulation of two-wheeled parking is 19 and parking capacity is 8 , so the results of the parking index analysis are as follows

$$
\begin{aligned}
\text { IP } & =\frac{\text { Parking Accumulated }}{\text { Parking capacity }} \\
& =\frac{\mathbf{1 9}}{\mathbf{8}} \\
& =2,37 \text { vehicle } / \text { square }
\end{aligned}
$$

The analysis results show that the motorbike parking index is 2.37 vehicles / plot. The results of the analysis show that IP> 1 means that the parking facility is problematic, where the parking requirement exceeds the normal capacity / capacity.

\section{- $\quad$ Four-wheeled parking index analysis}

The average accumulated four-wheeled parking is 2 and parking capacity is 1 so that the parking index analysis results are as follows:

$$
\begin{aligned}
\mathrm{IP} & =\frac{\text { Akumulasi Parkir }}{\text { Kapasitas Parkir }} \\
& =\frac{2}{2} \\
& =1 \mathrm{vehicle} / \mathrm{square}
\end{aligned}
$$

The results of the analysis can be seen that the car park index is 1.0 vehicle / plot. The results of the analysis show that IP $\geq 1$ means that parking requirements are balanced with normal capacity.

\section{- $\quad$ Parking Space Requirements Analysis}

Parking Space Unit (SRP) is the effective area to park one vehicle (passenger car, truck, motorbike) including free space and the width of the door opening. The results of the Parking Space Unit analysis can be obtained using the following formula:

$$
\mathrm{Z}=\mathrm{Y} \times \mathrm{D}: \mathrm{T}
$$

Information:

Z: Parking Space Unit (SRP)

Y: Number of vehicles

D: Average duration

T: Length of observation time (6 hours)

\section{- Two-wheeled Parking Space Unit (SRP) analysis}

The data on the number of vehicles in the 15 minute period were 86 vehicles, the survey duration was 6 hours and the average parking duration was 10 minutes / vehicle so that the results of the Parking Space Unit analysis were as follows:

$$
\begin{aligned}
\mathrm{Z} & =\mathrm{Y} \times \mathrm{D}: \mathrm{T} \\
& =86 \times 10 / 6 \\
& =143 \mathrm{SRP}
\end{aligned}
$$

The results of analysis can be seen that the average motorized parking space unit is 129 spaces. This exceeds the existing parking capacity, namely 65 parking lots, making the parking lot for twowheeled vehicles problematic or not like a parking space for accommodating existing vehicles. Based on the results of this analysis, it is known that the capacity of the parking space unit exceeds the 
number of parking lots, which is 64 spaces, so it is necessary to provide 64 parking spaces/parking lots and the lack of parking space, it is planned to be located south of the landungsari market which is considered still empty land.

\section{- $\quad$ Four-wheeled parking space unit/ SRP analysis}

Data on the number of vehicles in a period of 15 minutes is 20 vehicles, the survey takes 6 hours and the average parking duration is 10 minutes / vehicle so that the results of the Parking Space Unit analysis are as follows:

$$
\begin{aligned}
\mathrm{Z} & =\mathrm{Y} \times \mathrm{D}: \mathrm{T} \\
& =20 \times 10 / 6 \\
& =33 \mathrm{SRP}
\end{aligned}
$$

The results of the above analysis can be seen that the average car parking space unit is 11 spaces. This is less than the existing parking capacity, which is 20 parking lots, making the parking lot for four-wheeled vehicles not problematic or still like a parking lot in accommodating the number of vehicles.

\section{- Solutions and alternatives}

Based on the results of this analysis, it is known that the capacity of the parking space unit exceeds the number of parking lots, which is 64 spaces, so it is necessary to provide 64 parking spaces/parking lots and with the lack of parking space, it is planned to be located south of the landungsari market which is considered still visible empty land.

The addition of parking lots uses the southern market land which is the exit for the vehicle parking lot because the southern part of the market still looks empty so it can be used as a twowheeled parking lot. Also, parking lots for two-wheeled vehicles need to be marked with lines as parking boundaries between motorbikes and another by using the standard Decree of the DirectorGeneral of Land Transportation Number: 272 / Hk. 105 / Drjd / 96 concerning Technical Guidelines for the Implementation of Parking Facilities, namely $0,75 \mathrm{~m}$ x $2 \mathrm{~m}$ for two-wheeled vehicles and for four-wheeled vehicles, namely $3.4 \mathrm{~m} \times 12.5 \mathrm{~m}$ so that motorcyclists and cars do not park outside the parking area.

\section{Conclusion}

1) The results of the analysis of parking characteristics show that the average parking duration for motorbikes is 10 minutes/vehicle and the average car parking duration is 10 minutes/vehicle, the average accumulated parking for motorbikes is 19 vehicles and the average car parking accumulation is 2 vehicles, the capacity The average parking rate is known for two-wheeled vehicles at 8 vehicles/hour and four-wheeled vehicles as many as 21 vehicles/hour. This means that the number of parking lots is still less than the number of vehicles parked, namely for twowheeled parking lots.

2) Parking feasibility analysis is seen based on the parking index and parking space requirements as follows: it is known that the motorbike parking index is 2.37 vehicles/plot and the car park index is 2 vehicles/plot. The results of the analysis show that IP $>1$ means that the parking facility is problematic, where the parking requirement exceeds the normal capacity, while the average motorbike parking space unit is 129 parking spaces and the average car parking space unit is 11 parking spaces. These are considered inadequate parking facilities.

3) Parking solutions at the Malang Landungsari market include additional parking plots so as to increase vehicle parking capacity, especially for two-wheeled vehicles. Addition of parking lots using the southern market land which is the exit for parking vehicles because in the southern part of this market it still looks empty so that it can be used as a two-wheeled parking lot In addition to parking plots for two-wheeled vehicles need to be given lines as parking boundaries between one motorbike with others. 


\section{References}

[1] R. Widiyanto, Digital Imaging Series: Indonesia Culture, Kelima. Jakarta: Elex Media Komputindo, 2009.

[2] P. R. N. 43, "Peraturan Pemerintah Republik Indonesia Nomor 43 Tahun 1993 Tentang Prasarana dan Lalu Lintas Jalan," Peraturan Pemerintah Republik Indonesia. p. 78, 1993, [Online].

Available: http://jdih.dephub.go.id/assets/uudocs/pp/1993/pp_no_43_tahun_1993.pdf.

[3] U.-U. R. INDONESIA and N. 22 T. 2009, "www.hukumonline.com," 2009.

[4] F. . Hobbs, Perencanaan dan teknik lalu lintas. Yogyakarta: Gadjah Mada University Press, 1995.

[5] A. P. Numberi, P. Bahtiar, M. Perencanaan, U. Cenderawasih, and J. R. Abepura-sentani, "Analisis Karakteristik Parkir terhadap Kebutuhan Ruang Parkir di Pasar Central Hamadi Kota Jayapura Analysis of Vehicle Parking Characteristics on the Need for Vehicle Parking Spaces at the Hamadi Central Market Jayapura City Pertumbuhan ekonomi di Kota J," vol. 3, pp. 57-70, 2021.

[6] S. Warpani, Merencanakan sistem perangkutan. Bandung: ITB, 1990.

[7] A. A. J. Wikrama, "Analisis Karakteristik Dan Kebutuhan Parkir Di Pasar Kreneng," J. Ilm. Tek. Sipil, vol. 14, no. 2, pp. 158-170, 2010.

[8] Sugiyono, Prof. dr. sugiyono, metode penelitian kuantitatif kualitatif dan $r \& d$, 10th ed. Bandung: Alfabeta, 2007.

[9] O. Tamin, Perencanaan dan pemodelan transportasi. Bandung: ITB Press, 2000.

[10] A. Munawar, Manajemen Lalu Lintas Perkotaan. Yogyakarta: Yogyakarta: Beta Offset, 2004, 2004. 